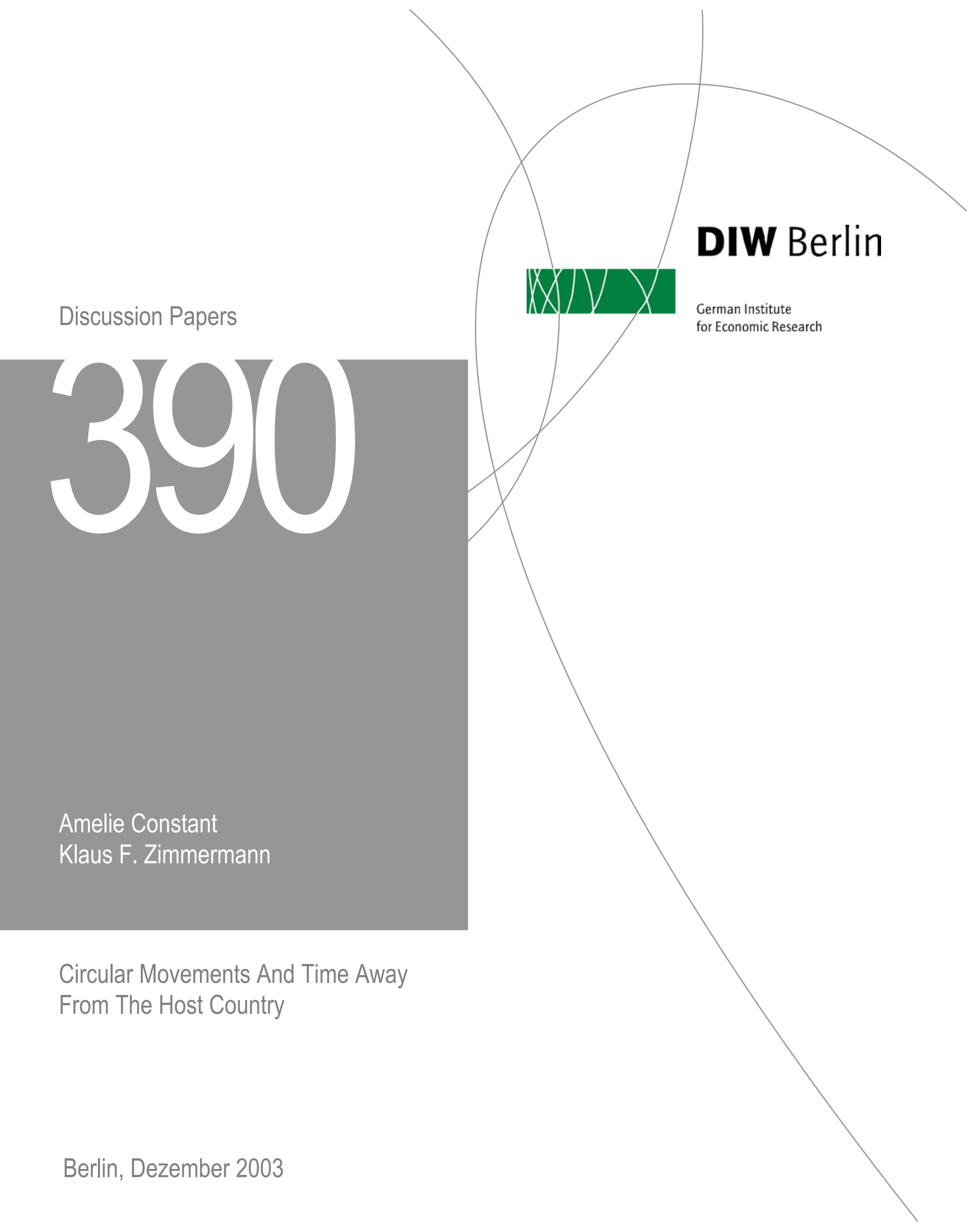


Opinions expressed in this paper are those of the author and do not necessarily reflect views of the Institute.

\section{DIW Berlin}

\section{German Institute}

for Economic Research

Königin-Luise-Str. 5

14195 Berlin,

Germany

Phone $+49-30-89789-0$

Fax +49-30-897 89-200

www.diw.de

ISSN 1619-4535 


\title{
CIRCULAR MOVEMENTS AND TIME AWAY FROM THE HOST COUNTRY*
}

\author{
Amelie Constant \\ IZA, Bonn, and University of Pennsylvania \\ Constant@iza.org \\ and \\ Klaus F. Zimmermann \\ Bonn University, IZA, Bonn, and DIW Berlin \\ Zimmermann@iza.org
}

December 2003

\begin{abstract}
The economic literature has largely overlooked the importance of repeat migration. This paper studies repeat or circular migration as it is manifested by the frequency of exits of migrants living in Germany, and by the number of years being away from the host country using count data models. More than $60 \%$ of the guestworker generation currently living in Germany, the largest European immigration country, are indeed repeat migrants. The findings indicate that immigrants from European countries, the less educated, those with weak labor market attachements, the younger and the older people (excluding the middle ages), and the newcomers and the more seasoned are significantly more likely to engage in circular migration and to stay out of Germany for longer. Males exit more frequently than females but do not differ in the time spent out. Those migrants with family in the home country remain out longer but are not more frequently out.

Keywords: Repeat migration, circular migration, guestworkers; minorities JEL classification: F22; J15; J61

* Klaus F. Zimmermann is Professor of Economics at Bonn University, Honorary Professor at the Free University of Berlin, Director of the Institute for the Study of Labor (IZA), and President of the German Institute for Economic Research (DIW Berlin). Amelie Constant is Senior Research Associate and Deputy Program Director for Migration at the Institute for the Study of Labor (IZA), and Visiting Scholar at the Population Studies Center of the University of Pennsylvania. The authors would like to thank seminar participants at the IZA Research Seminar for helpful comments and suggestions. The GSOEP data basis used in this study is available upon request from the German Socio-Economic Panel at DIW Berlin (www.diw.de/gsoep).
\end{abstract}

Corresponding author:

Klaus F. Zimmermann

IZA, P.O. Box 7240

D-53072 Bonn, Germany

Phone: +49 2283894200

Fax: +49 2283894210 
For the traditional immigration countries, migration has often been perceived as a one time discrete move from the home to the host country, and return migration has been regarded as a move from the host back to the home country. These movements have attracted substantial research activities. An overview of this literature and some key collected research papers on the migration and return migration decisions are contained in Zimmermann and Bauer (2002). However, it has now become a reality that circular, repeat, recurrent, revolving door, multiple, frequent, repetitive, intermittent, seasonal, sojourning, cyclical, recycling, chronic or shuttling migration is a salient trait of migration. Circular migration, as we call it here in short, is a common practice by many of the migrants of today. Unfortunately, the literature on multiple moves in an international setting is rather scarce. The classical contribution by DaVanzo (1983) is an examination of internal repeat migration in the United States. Most of the contributions are from sociology. For instance, Massey and Espinosa (1997) have established that Mexicans moving into the United States are indeed circular migrants. They have shown that this phenomenon is even more common than return or onward migration. Using the example of Puerto Ricans, Tienda and Diaz (1987) have argued that circular migration (here to the United States) can be disastrous for families, employment and income, when return migrants face high unemployment in the home country and are forced to migrate again. They suggest that circular migration might have contributed to a rapid increase in female-headed families, high school dropout rates, and a lack of training and work experience.

A recent article in the Wall Street Journal (Porter 2003) has made it clear that the issue of circular migration is even relevant for illegal migrants. The ability to go back and forth between the home and the host country and its consequences for both economies is 
discussed in the context of Mexican migration to the United States. Originally, this was a temporary, male dominated workforce going home regularly to support the family with money earned abroad. Many communities especially in California enjoyed the advantages of cheap labor without experiencing the problems with entrenched communities of lowincome workers and their families. Now with the much stricter border controls the behavior of Mexican migrants has changed. While this has not stopped people from coming, they are much less inclined to circularly return, but bring their families instead. Since the early 1980 s, where an undocumented Mexican worker stayed about three years on the average, the duration of stay has increased to nine years in the late 1990s.

That restrictive migration policies can turn out to be rather counter-productive had been observed before. A quite similar problem had appeared in major European countries including Germany, when in 1973 the labor hiring regime was abolished abruptly in the face of rising unemployment (Zimmermann 1996). As a consequence, many migrants from the guestworker generation stopped going home and induced a substantial rise in family reunifications. Now, only a smaller portion of the migrants work, and they exhibit high unemployment rates and substantial take-ups of social assistance.

Hence, the issue of how circular migration develops and how those migrants integrate in the host country is of substantial political importance. The way migrants will attach themselves to the labor force and to society largely depends on their moving strategy. However, there is hardly any empirical literature on this new type of migration. To fill this gap, the paper aims to answer the following questions: What are the determinants of circular migration and what are the socioeconomic characteristics of the immigrants who practice it? What is the frequency of exits and what determines the time spend home? Do 
circular immigrants respond to the general situation in the host economy, namely their unemployment experiences? Or, is circular migration just an optimization device?

\section{The Economics of Circular Migration}

The literature on migration has established that return migration is considerable and highly selective (Borjas 1989, Dustmann 1996, and Constant and Massey 2002, 2003). However, once a move has taken place, immigrants are more prone to move again. Each move builds the momentum of a self-sustaining repeat migration through the accumulation of "migration-specific capital" (Massey and Espinosa 1997), and hence, circular migration develops. However, little is known empirically about it, mainly due to the non-availability of suitable longitudinal data. (For a recent exception see Constant and Zimmermann 2003.)

Return migration might occur ex post due to the realization of sub-optimal decisions as a corrective mechanism or due to ex-ante predetermined and preplanned decisions to return. Accordingly, return migration is viewed as a one-time event. Circular migration, however, while it has the appearance of an indecisive perpetual move, it might be a way of optimizing or re-optimizing one's economic, social, and personal situation at every period. Put differently, circular migration might be a way of taking advantage of opportunities as they appear in both the host and home country. Circular migration might also denote strong preferences for frequent locational changes in maximizing utility.

In a way, circular migration helps to keep the migrant's options open for both the host and the home countries, and reduces the risks of a long term commitment. Recurrent immigrant movement back and forth across the border is, indeed, a common strategy 
among Mexicans in the United States. Further, while the initial move to the host country is governed by uncertainty, circular migration decisions are operating under a more complete information set, thereby reducing search, relocation, and psychic costs. Multiple movers have the comparative advantage of building and accumulating location-specific capital.

Circular migratory moves might also include temporary motives: students who go to the home country to attend college, young adults who return to join the army for the obligatory service, and immigrants who go to the home country to find a spouse. There is also the case of employment or intra-company transfers, i.e. taking advantage of promotions and upward mobility, and the issue of circular moves of retirees.

In this paper we study the frequency of exits of a migrant population from and back to the host country as well as the amount of time spent out of the host country. An exit is defined as the absence of at least a year until the subsequent return. We seek to identify the underlying factors that cause individuals to frequently move in between the host and the home countries and the time spent outside of the host country at home. We seek to answer the following questions: What are the probabilities that immigrants follow the path of repeatedly crossing the borders between the host and the home countries? Do circular immigrants respond to the general situation in the economy, namely their unemployment experiences? Is circular migration a way of maximizing one's well-being? Or is circular migration the prelude of a long-term permanent installation? What are the socioeconomic characteristics of the individuals who practice circular migration? Does circular migration occur mainly during the younger years or does it persist throughout the immigrant's life? We control for gender differences, human capital, country of origin, and employment characteristics. We further compare the stayers (immigrants who stayed in the host country 
without interruption) with the chronic movers (immigrants who move from one country to another and back).

Few studies have examined the phenomenon of circular migration between the host and the home countries, and little is known about the characteristics of these migrants. Among the first to study the phenomenon of perpetuating migration between the United States and Mexico, is Massey (1987). Investigating the frequency of trips from Mexico to the United States and back he established that the progression from one trip to the next is determined by variables connected with the migrant experience itself, while social networks play an important role in undertaking an additional trip. In contrast, age, education, marital status, presence of children, and land ownership are unrelated to the likelihood of making an additional trip. Looking at repeated illegal trips by Mexican immigrants to the U.S. the Donato et al. (1992) study showed that older immigrants are less likely to undertake a second illegal trip but the likelihood of an additional trip increase with the number of previous trips. While the 1986 Immigration Reform and Control Act had no effect in deterring recurrent illegal migration, they also found that even apprehension does not deter migration. In fact, immigrants who have embarked on a career of recurrent U.S. migration are less likely to alter their deportment.

In a later study, Massey and Espinosa (1997) examined the odds of taking an additional trip to the United States, for both documented and undocumented migrants, given that at least one trip had already occurred. They found that immigrants who practice circular migration display significantly different characteristics. The odds of circular migration progressively increase with experience, occupational achievement, and prior trips in the United States, suggesting a self-perpetuating nature of migration. The likelihood of taking 
another trip to the United States is also reinforced by social capital that is created through circular migration. However, they found that controlling for migration-specific human and social capital, the variables that were of the essence in determining initial migration become less important in forecasting circular migration. Nevertheless, among undocumented immigrants, amnesty to a family member, increases the odds of taking an additional trip.

Whereas it has been argued that for the Puerto Ricans, for example, circular migration has hampered them from moving up economically and establishing roots in one country (Tienda and Diaz 1987), no empirical studies have proven this argument. Many immigrants continue to maintain businesses, homes, and families in Mexico while they are moving back and forth seasonally (Durand and Massey 1992).

\section{Data, Variables and Methods}

Our empirical analysis uses data from Germany, the largest European immigration country, namely from the German Socioeconomic Panel (GSOEP), a nationally representative survey with outstanding quality and reputation provided by DIW Berlin, the German Institute for Economic Research (SOEP Group, 2001). For this study, we were able to include 14 waves from 1984 - 1997 of migrants from the guestworker generation who were not in the military, were over 16 years of age and were successfully interviewed in a given year. The final sample contains 4,613 migrants, with 2,231 of them being females. Re-migration in the sample is substantial. 2,857 individuals have excited Germany at least once during this period. They constitute 62 percent of all guestworkers in our sample.

In our analysis we employ a standard set of human capital and socioeconomic status variables. Our main interest is in how these characteristics influence migrants to exhibit 
circular movements. Our dependent variables are the number of exits from Germany and the number of years out of Germany. An exit is defined as an absence of at least one year out of Germany and a return back to Germany.

With regards to the independent variables, human capital is captured by education and language. The education variable includes both pre- and post-migration education. Because of the specificity of the German educational system the education variable also embodies vocational training. This is a better measure of human capital because in addition to formal education it includes the effect of training on occupational attainment. We capture experience by age and years of residence in Germany. For the labor market characteristics we include employment status - whether full or part time - and occupational prestige of the last occupation before the first exit. We also include remittances since circular migration to the home country is also likely to increase remittance flows.

Lastly, we include variables that capture social and psychological ties to the respective countries. Namely, owning one's own home in Germany would indicate a successful adaptation in Germany and will lower the likelihood of repeated moves. Likewise, if one's spouse and children are in the home country this will increase the likelihood of repeated moves. Although being a German citizen could indicate that the immigrant "feels at home" in Germany and would be reluctant to go back to the home country, at the same time German citizenship gives the opportunity to be able to travel back and forth without being subject to migration restrictions. The same rationale applies to EU nationals, who we expect to exhibit a higher probability to repeated moves.

In a count data framework (Cameron and Trivedi 1998; Winkelmann 2000), we estimate two models. Our first approach studies the frequency of the moves out of 
Germany, and the second examines the total number of years spent out of Germany in across all time periods of our sample. For this exercise we employ robust Poisson regressions, and we test against more general alternatives. To control for the fact that some immigrants enter the sample later and to normalize the observation period, we introduced two exposure variables as regressors in the count data estimation. An implication of this is that we enforce equal presence of the individuals. The exposure variable is the maximum number of possible exits for each particular individual in the case of the frequency of the moves, and the maximum number of potential years out of the country in the case of the study of the duration of absence. Individuals were considered in their first year in the panel, and we regressed the number of exits or years spent out of Germany on the socioeconomic characteristics of an immigrant during that year. For the circular migrants, this year is the year before the first exit out of Germany.

\section{Empirical Evidence}

Table 1 presents the summary statistics for the selected variables in the analysis. These statistics are tabulated separately for the entire sample, the immigrants who left Germany at least once, and the immigrants who never left Germany. As expected, there are differences between these groups. On average, the circular immigrants are 4 years older than the stayers, and most of the circular moving occurs by people who are between 25 and 64 years of age before they first exit. While both groups have about 14 years of residence in Germany they do not have accumulated much human capital. Overall, the circular migrants have less education acquired in Germany and more in the home country. Compared to the immigrants who stay in Germany, a larger percentage of the circular migrants never went to 
school in Germany, a smaller percentage of them acquired higher education, and a smaller percentage of them speak the German language fluently.

These raw statistics also show that a larger percentage of the circular migrants are employed full time in Germany although their occupational prestige score is not very different from the occupational score of the stayers. Circular migrants tend to remit more to the home country, they tend not to own their own house in Germany, and not to acquire the German citizenship. Among circular migrants, 41\% are from EU countries as opposed to $27 \%$ among the stayers. Moreover, the majority of circular migrants are married with a larger percentage having their spouse and children in the home country.

When it comes to feeling attached and comfortable in Germany, whether stayers or circular migrants, only about 3\% of the guestworkers in Germany feel German. Lastly, the average circular migrant has spent about 7 years out of his tenure in Germany and has exited and returned more than once. In general, these characteristics show that although the immigrants who repeatedly cross the borders are more likely to be employed and, indeed full-time employed, they do not feel attached to the German sociocultural society, while they maintain strong ties with the countries of origin.

Our analysis of count data models involved the estimation of a standard Poisson regression model, while the traditional negative binomial regression and other more general alternatives were not found to be appropriate. First, simple overdispersion tests were employed using the parameter estimates of the standard poisson regression model (Greene 2000: 884-885). We use two standard tests that examine the departure from the standard poisson assumption of the equality of the mean and the variance. The first test (see also $\mathrm{G}(\mu)$ in Table 2) examines an alternative where the difference between the variance and the 
mean is a constant times the mean. The second test (see also $\mathrm{G}\left(\mu^{2}\right)$ in Table 2) examines an alternative where the difference between the variance and the mean is a constant times the squared of the mean. The latter test suggests the validity of the most popular alternative specification used in the literature, namely the Negative Binomial Regression model.

Table 2 shows that the number of exists exhibits no overdispersion, while there is some (for $G(\mu)$ ) in the case of the number of years out of Germany. This implies that in both cases the Negative Binomial Regression model is not appropriate. However, the Poisson parameter estimates are consistent under a wider class of count data models, but the standard errors are too low (too high) in the case of over-(under-)dispersion. To avoid such a potential bias, we thus, calculated robust standard errors, which are able to deal with any kind of dispersion.

In Table 2 we present the empirical estimates from the Poisson regression as they predict the frequency of exits and years out (columns 2 and 4 respectively). In columns 3 and 5 we present the marginal effects of the 2 models. For both models, the age pattern with regards to the likelihood of repeated moves and years out of Germany is that of a Ushape. Younger immigrants are less likely to engage in circular migration or to stay out for more years but as they grow older they are more likely to go out more often and to stay out longer. With regards to years since migration, the likelihood of circular migration decreases with additional years since migration when one has only a few years of migration accumulated in Germany, but this likelihood increases when one has spent more years in Germany.

Those immigrants who have some years of schooling in their home country before they migrated have a lower proclivity to circular migration and lower proclivity to stay out for 
longer periods. Similarly, immigrants who have acquired education in Germany, whether formal schooling or vocational training, are less likely to become circular migrants and less likely to stay out of Germany for long. For example, the migrants who obtained higher education in Germany, as opposed to those who never went to school in Germany, will exit 0.24 times less and stay 1.32 less years abroad. Further, immigrants who are employed in Germany whether full or part time have a lower probability to exit Germany and a lower probability to stay out for longer periods.

Moreover, for both models, we find that the immigrants who have become German citizens and, thus, have unrestricted entry and exit into Germany and its labor market, have a significantly higher probability both to exit Germany frequently and to stay out of Germany longer. Immigrants who take the German passport exit and enter Germany 0.6 times more and they stay 3.21 more years out of Germany compared to the immigrants who have not become German citizens. By the same token, we find that the non-EU nationals in Germany, who fear that they will not be able to return once they are out of the country, have a lower probability to exit and to spend any years out of Germany. Specifically, Turks have an $8 \%$ lower probability to exit and $10 \%$ lower probability to stay out for a long period compared to EU nationals. They also exit 0.06 times less and stay in Turkey 0.47 years less than EU-nationals.

For the number of exits model specifically, we find that male immigrants are more prone to circular migration. They are $11 \%$ more likely to frequently go in and out of Germany and exit 0.08 times more than female immigrants. For the number of years out of Germany model, we find that the immigrants who own their house in Germany have a $28 \%$ lower probability to stay out of Germany for prolonged periods. Our results show that home 
ownership in Germany reduces the number of years one stays out of Germany by 1.3 years. Immigrants from ex-Yugoslavia have a $20 \%$ lower probability to stay out of Germany for more years and stay roughly for 1 year less abroad.

Whereas only a small percentage of the guestworkers have left their spouses back in the home country, this fact significantly increases the probability to spend more years out of Germany, as expected. Having their spouses back in the home country increases their time outside Germany by a whole year. In contrast, having young children in the household significantly decreases the probability to spend more years out of Germany. This could occur because parents do not want to disrupt their children's education by moving them for long periods out of Germany or because these youngsters feel that Germany is their home and refuse to let their parents undertake longer spells outside Germany.

\section{Summary and Policy Discussion}

In this paper we considered the phenomenon of repeat or circular migration as it is manifested by the frequency of entry and exits from Germany and by the time spend outside of Germany. Based on the German Socio-Economic Panel (GSOEP), we estimated robust Poisson models to explain the guestworkers' behavior. We find that migrants who do not face restrictions to reenter into Germany (like members from EU countries), who are less educated (either from the home or the host country), those with no labor market attachment in Germany, and those who carry a German passport are significantly more likely to engage in circular migration and to stay out of Germany for longer. This also holds for younger or older individuals and for recent or permanent immigrants, while both 
variables exhibit a non-linear relationship. These findings point to the fact that circular migrants are bi-modal, they either are more seasoned or they are newcomers. Male guestworkers are more frequently out, but are not different from females in the overall time spend home. Those, who do not own real estate in Germany, have a spouse in the home country and no under-age children in Germany stay significantly longer time periods out of Germany but are not significantly more likely to engage in circular migration measured by the number of exists.

We conclude that circular migration is indeed an important phenomenon that should receive more attention among researchers and policy-makers. Since the mid-seventies, tighter mobility constraints had caused a decline in return migration among the guestworkers in Germany because they were unable to re-enter easily. As shown in this paper, the same happens with the phenomenon of circular migration. If such a phenomenon is considered to be beneficial since it increases the flexibility of the host country to react to labor market conditions, it should be fostered rather that made difficult. This may also affect our evaluation of illegal migration. As we recently saw in the United States, tighter controls at the Mexican border have caused the odd result that more illegals stay, which seems to appear as a counter-productive policy measure. 
TABLE 1: SELECTED SAMPLE CHARACTERISTICS BEFORE THE FIRST EXIT FROM GERMANY Entire Sample Left Germany at least Never left Germany

\begin{tabular}{|c|c|c|c|c|c|c|}
\hline \multirow[b]{2}{*}{ Variables } & \multicolumn{6}{|c|}{ once } \\
\hline & Mean & Std.Dev. & Mean & Std.Dev. & Mean & Std.Dev. \\
\hline Male & 0.516 & 0.500 & 0.523 & 0.500 & 0.505 & 0.500 \\
\hline Age & 31.542 & 13.121 & 32.888 & 13.579 & 29.351 & 12.026 \\
\hline Age (16-18) & 0.235 & 0.424 & 0.203 & 0.403 & 0.285 & 0.452 \\
\hline Age (19-24) & 0.173 & 0.379 & 0.168 & 0.374 & 0.182 & 0.386 \\
\hline Age (25-64) & 0.588 & 0.492 & 0.622 & 0.485 & 0.531 & 0.499 \\
\hline Age $(65+)$ & 0.004 & 0.066 & 0.006 & 0.077 & 0.002 & 0.041 \\
\hline Years Since Migration & 14.492 & 7.792 & 14.474 & 7.467 & 14.522 & 8.295 \\
\hline No Degree in Germany & 0.723 & 0.448 & 0.747 & 0.435 & 0.683 & 0.466 \\
\hline Primary-Secondary Education in Germany & 0.175 & 0.380 & 0.181 & 0.385 & 0.165 & 0.371 \\
\hline Higher Education in Germany & 0.103 & 0.303 & 0.072 & 0.259 & 0.152 & 0.359 \\
\hline Vocational Training in Germany & 0.166 & 0.372 & 0.168 & 0.374 & 0.162 & 0.369 \\
\hline Speaking German Fluently & 0.209 & 0.407 & 0.193 & 0.395 & 0.236 & 0.425 \\
\hline Education in Native Country & 4.470 & 3.595 & 4.699 & 3.485 & 4.099 & 3.738 \\
\hline Fulltime Employed & 0.472 & 0.499 & 0.492 & 0.500 & 0.440 & 0.497 \\
\hline Not Employed & 0.365 & 0.482 & 0.343 & 0.475 & 0.402 & 0.490 \\
\hline Employed & 0.577 & 0.494 & 0.597 & 0.491 & 0.546 & 0.498 \\
\hline Prestige of Job in Germany & 31.694 & 11.302 & 31.893 & 11.156 & 31.371 & 11.533 \\
\hline Remit to Home Country & 0.217 & 0.412 & 0.239 & 0.427 & 0.180 & 0.384 \\
\hline Own Dwelling in Germany & 0.070 & 0.255 & 0.059 & 0.235 & 0.088 & 0.284 \\
\hline German Citizen & 0.163 & 0.370 & 0.131 & 0.337 & 0.216 & 0.412 \\
\hline Turk & 0.324 & 0.468 & 0.321 & 0.467 & 0.330 & 0.470 \\
\hline ex-Yugoslav & 0.156 & 0.363 & 0.140 & 0.347 & 0.182 & 0.386 \\
\hline EU-Citizen & 0.356 & 0.479 & 0.408 & 0.492 & 0.272 & 0.445 \\
\hline Not Married & 0.389 & 0.488 & 0.370 & 0.483 & 0.419 & 0.493 \\
\hline Married & 0.611 & 0.488 & 0.630 & 0.483 & 0.581 & 0.493 \\
\hline Married Spouse not in Germany & 0.028 & 0.166 & 0.035 & 0.183 & 0.018 & 0.134 \\
\hline Kids in the Household & 0.605 & 0.489 & 0.608 & 0.488 & 0.601 & 0.490 \\
\hline Kids in Native Country & 0.070 & 0.256 & 0.078 & 0.268 & 0.058 & 0.234 \\
\hline Feel German & 0.034 & 0.182 & 0.035 & 0.183 & 0.034 & 0.180 \\
\hline Number of Years out of Germany & 4.555 & 4.903 & 7.354 & 4.270 & 0 & 0 \\
\hline Number of Exits out of Germany & 0.700 & 0.622 & 1.130 & 0.372 & 0 & 0 \\
\hline Time in the Panel & 7.417 & 4.880 & 5.686 & 4.191 & 10.232 & 4.602 \\
\hline Observations & & & & & & \\
\hline
\end{tabular}


TABLE 2: NUMBER OF YEARS AND EXITS OUT OF GERMANY; POISSON REGRESSION WITH ROBUST STANDARD ERRORS AND MARGINALS

\begin{tabular}{|c|c|c|c|c|}
\hline \multirow[b]{2}{*}{ Variables } & \multicolumn{2}{|c|}{ Number of Exits out of Germany } & \multicolumn{2}{|c|}{ Number of Years out of Germany } \\
\hline & $\begin{array}{c}\text { Coefficients } \\
\text { (Standard Error) }\end{array}$ & $\begin{array}{l}\text { Marginal Effects } \\
\text { (Standard Error) }\end{array}$ & $\begin{array}{c}\text { Coefficients } \\
\text { (Standard Error) }\end{array}$ & $\begin{array}{l}\text { Marginal Effects } \\
\text { (Standard Error) }\end{array}$ \\
\hline$\overline{\text { Age }}$ & $\begin{array}{l}-0.085^{*} \\
(0.009)\end{array}$ & $\begin{array}{l}-0.059^{*} \\
(0.010)\end{array}$ & $\begin{array}{l}-0.083^{*} \\
(0.009)\end{array}$ & $\begin{array}{l}-0.378^{*} \\
(0.068)\end{array}$ \\
\hline $\mathrm{Age}^{2}$ & $\begin{array}{c}0.001^{*} \\
(0.0001)\end{array}$ & $\begin{array}{l}0.001^{*} \\
(0.0001)\end{array}$ & $\begin{array}{l}0.001^{*} \\
(0.0001)\end{array}$ & $\begin{array}{l}0.004^{*} \\
(0.001)\end{array}$ \\
\hline Years since Migration & $\begin{array}{l}-0.010 \\
(0.006)\end{array}$ & $\begin{array}{l}-0.007 \\
(0.006)\end{array}$ & $\begin{array}{l}-0.012^{*} \\
(0.006)\end{array}$ & $\begin{array}{c}-0.056 \\
(0.035)\end{array}$ \\
\hline Years since Migration² & $\begin{array}{l}0.0003^{*} \\
(0.0001)\end{array}$ & $\begin{array}{l}0.0002^{*} \\
(0.0001)\end{array}$ & $\begin{array}{l}0.0003^{*} \\
(0.0001)\end{array}$ & $\begin{array}{l}0.001^{*} \\
(0.001)\end{array}$ \\
\hline Education in Home Country & $\begin{array}{l}-0.023^{*} \\
(0.006)\end{array}$ & $\begin{array}{l}-0.016^{*} \\
(0.005)\end{array}$ & $\begin{array}{l}-0.013^{*} \\
(0.006)\end{array}$ & $\begin{array}{l}-0.060 \\
(0.035)\end{array}$ \\
\hline Primary-Secondary Education in Germany & $\begin{array}{l}-0.340^{*} \\
(0.062)\end{array}$ & $\begin{array}{l}-0.238^{*} \\
(0.060)\end{array}$ & $\begin{array}{l}-0.227^{*} \\
(0.065)\end{array}$ & $\begin{array}{l}-1.033^{*} \\
(0.395)\end{array}$ \\
\hline Higher Education in Germany & $\begin{array}{l}-0.338^{*} \\
(0.091)\end{array}$ & $\begin{array}{l}-0.236^{*} \\
(0.083)\end{array}$ & $\begin{array}{l}-0.290^{*} \\
(0.094)\end{array}$ & $\begin{array}{l}-1.321^{*} \\
(0.568)\end{array}$ \\
\hline Vocational Training in Germany & $\begin{array}{l}-0.139^{*} \\
(0.053)\end{array}$ & $\begin{array}{l}-0.097^{\star} \\
(0.048)\end{array}$ & $\begin{array}{l}-0.128^{*} \\
(0.056)\end{array}$ & $\begin{array}{l}-0.584 \\
(0.335)\end{array}$ \\
\hline Speaking German Fluently & $\begin{array}{c}0.045 \\
(0.049)\end{array}$ & $\begin{array}{c}0.032 \\
(0.043)\end{array}$ & $\begin{array}{l}-0.006 \\
(0.052)\end{array}$ & $\begin{array}{l}-0.027 \\
(0.301)\end{array}$ \\
\hline Employed in Germany & $\begin{array}{l}-0.070^{*} \\
(0.036)\end{array}$ & $\begin{array}{l}-0.049 \\
(0.032)\end{array}$ & $\begin{array}{l}-0.104^{*} \\
(0.038)\end{array}$ & $\begin{array}{l}-0.472^{*} \\
(0.228)\end{array}$ \\
\hline Prestige of Job in Germany & $\begin{array}{c}-0.0004 \\
(0.002)\end{array}$ & $\begin{array}{c}-0.0003 \\
(0.001)\end{array}$ & $\begin{array}{c}-0.002 \\
(0.002)\end{array}$ & $\begin{array}{c}-0.011 \\
(0.010)\end{array}$ \\
\hline Remit to Home Country & $\begin{array}{l}-0.040 \\
(0.035)\end{array}$ & $\begin{array}{c}-0.028 \\
(0.031)\end{array}$ & $\begin{array}{c}-0.009 \\
(0.040)\end{array}$ & $\begin{array}{c}-0.041 \\
(0.235)\end{array}$ \\
\hline Own Dwelling in Germany & $\begin{array}{c}-0.132 \\
(0.078)\end{array}$ & $\begin{array}{c}-0.092 \\
(0.069)\end{array}$ & $\begin{array}{l}-0.276^{*} \\
(0.083)\end{array}$ & $\begin{array}{l}-1.258^{*} \\
(0.502)\end{array}$ \\
\hline German Citizen & $\begin{array}{c}0.852^{*} \\
(0.075)\end{array}$ & $\begin{array}{l}0.596^{*} \\
(0.094)\end{array}$ & $\begin{array}{l}0.704^{*} \\
(0.088)\end{array}$ & $\begin{array}{l}3.207^{*} \\
(0.636)\end{array}$ \\
\hline Turk & $\begin{array}{l}-0.081^{*} \\
(0.035)\end{array}$ & $\begin{array}{l}-0.057 \\
(0.031)\end{array}$ & $\begin{array}{l}-0.104^{*} \\
(0.037)\end{array}$ & $\begin{array}{l}-0.471^{*} \\
(0.224)\end{array}$ \\
\hline ex-Yugoslav & $\begin{array}{l}-0.071 \\
(0.043)\end{array}$ & $\begin{array}{c}-0.050 \\
(0.038)\end{array}$ & $\begin{array}{l}-0.204^{*} \\
(0.049)\end{array}$ & $\begin{array}{l}-0.930^{*} \\
(0.303)\end{array}$ \\
\hline Male & $\begin{array}{l}0.114^{*} \\
(0.034)\end{array}$ & $\begin{array}{l}0.079^{*} \\
(0.031)\end{array}$ & $\begin{array}{c}0.039 \\
(0.036)\end{array}$ & $\begin{array}{c}0.177 \\
(0.210)\end{array}$ \\
\hline Married & $\begin{array}{l}-0.091 \\
(0.048)\end{array}$ & $\begin{array}{l}-0.064 \\
(0.043)\end{array}$ & $\begin{array}{l}-0.075 \\
(0.050)\end{array}$ & $\begin{array}{l}-0.341 \\
(0.296)\end{array}$ \\
\hline Married Spouse not in Germany & $\begin{array}{c}0.132 \\
(0.074)\end{array}$ & $\begin{array}{c}0.092 \\
(0.065)\end{array}$ & $\begin{array}{l}0.213^{*} \\
(0.078)\end{array}$ & $\begin{array}{l}0.969^{*} \\
(0.467)\end{array}$ \\
\hline Kids $<16$ Year Old in the Household & $\begin{array}{l}-0.001 \\
(0.036)\end{array}$ & $\begin{array}{c}-0.001 \\
(0.032)\end{array}$ & $\begin{array}{l}-0.114^{*} \\
(0.037)\end{array}$ & $\begin{array}{l}-0.520^{*} \\
(0.223)\end{array}$ \\
\hline Kids in Native Country & $\begin{array}{l}-0.004 \\
(0.052)\end{array}$ & $\begin{array}{l}-0.003 \\
(0.045)\end{array}$ & $\begin{array}{l}-0.019 \\
(0.058)\end{array}$ & $\begin{array}{l}-0.085 \\
(0.338)\end{array}$ \\
\hline Exposure in the Sample & 1 & $0.670^{*}$ & 1 & $4.555^{\star}$ \\
\hline Constant & $\begin{array}{l}-5.040^{\star} \\
(0.158)\end{array}$ & $\begin{array}{l}-3.526^{*} \\
(0.366)\end{array}$ & $\begin{array}{l}-9.00^{*} \\
(0.16)\end{array}$ & $\begin{array}{c}-40.993^{*} \\
(4.248)\end{array}$ \\
\hline Number of observations & & & & \\
\hline Log likelihood function & -523 & 197 & -221 & \\
\hline $\begin{array}{l}\text { Overdispersion test } G(\mu) \\
\text { Overdispersion test } G\left(\mu^{2}\right)\end{array}$ & & & & \\
\hline Overdispersion test $\mathrm{G}\left(\mu^{2}\right)$ & & & & \\
\hline
\end{tabular}




\section{REFERENCES}

Borjas, George J. 1989. "Immigrant and Emigrant Earnings: A Longitudinal Study." Economic Inquiry, Vol 27, No. 1 (January), pp. 21-37.

Cameron, Colin, and Pravin K. Trivedi. 1998. Regression Analysis of Count Data. Cambridge: Cambridge University Press.

Constant, Amelie, and Douglas S. Massey. 2002. "Return Migration by German Guestworkers: Neoclassical versus New Economic Theories." International Migration, Vol. 40, No. 4, pp. 5-38.

----. 2003. "Self-Selection, Earnings and Out-Migration: A Longitudinal Study of Immigrants." Journal of Population Economics, Vol. 16, No. 4, pp. 630-653.

Constant, Amelie, and Klaus F. Zimmermann. 2003. "The Dynamics of Repeat Migration: A Markov Chain Analysis." IZA Discussion Paper No. 885.

DaVanzo, Julie. 1983. "Repeat migration in the United States: Who Moves Back and Who Moves On?" Review of Economics and Statistics, Vol. 65, No. 4 (November), pp. 552559.

Donato, Katharine M., Jorge Durand, and Douglas S. Massey. 1992. "Stemming the Tide? Assessing the Deterrent Effects of the Immigration Reform and Control Act." Demography, Vol. 29, No. 2 (May), pp. 139-157.

Durand, Jorge, and Douglas S. Massey. 1992. "Mexican Migration to the United States: A Critical Review." Latin American Research Review. Vol. 27, No. 2, pp. 3-42.

Dustmann, Christian. 1996. "Return Migration: The European Experience." Economic Policy, Vol. 22 (April), pp. 214-250.

Greene, William. 2000. Econometric Analysis, 4th ed. Upper Saddle River, New Jersey: Prentice Hall.

Massey, Douglas S. 1987. "Understanding Mexican Migration to the United States." American Journal of Sociology, Vol. 92, No. 6 (May), pp. 1372-1403.

Massey, Douglas S., and Karen E. Espinosa. 1997. "What's Driving Mexico-U.S. Migration? A Theoretical, Empirical, and Policy Analysis." American Journal of Sociology, Vol. 102, No. 4 (January), pp. 939-999.

Porter, Eduardo. 2003. "Tighter Border Yields Odd Result: More Illegals Stay." The Wall Street Journal, October 10.

SOEP Group. 2001. "The German Socio-Economic Panel (GSOEP) after more than 15 years - Overview." In Elke Host, Dean R. Lillard, and Thomas A. DiPrete, eds., Proceedings of the 2000 Fourth International Conferences of German Socio-Economic Panel Study Users (GSOEP 2000), Quarterly Journal of Economic Research, Vol. 70, 
No. 1, pp. 7-14.

Tienda, Marta, and William Diaz. 1987. "Puerto Rican Circular Migration." The New York Times, August 28, p. A31.

Winkelmann, Rainer. 2000. Econometric Analysis of Count Data, 3rd ed. Berlin: SpringerVerlag.

Zimmermann, Klaus F. 1996. "European Migration: Push and Pull." International Regional Science Review. Vol. 19, No. 1, pp. 95-128.

Zimmermann, Klaus F., and Thomas Bauer. 2002. The Economics of Migration, Vol.1, The Migration Decision and Immigration Policy. Cheltenham, UK: Edward Elgar. 